\title{
Muscle Recovery Strategies Applied to Soccer Players: A Narrative Review
}

\section{Fellipe Lima Oliveira, Wanderson Divino Nilo dos Santos, Rodrigo dos Santos Guimarães, Naiany Pereira Silva and Vitor Alves Marques*}

Federal University of Goias, Physical Education College, Goiânia, Goiás, Brazil

*Corresponding Author: Vitor Alves Marques, Federal University of Goias,

Physical Education College, Goiânia, Goiás, Brazil.
Received: June 29, 2021

Published: July 21, 2021

(C) All rights are reserved by Vitor Alves

Marques., et al.

\begin{abstract}
Post-exercise recovery in sports is important, for the athelete a good recovery is essential for better performance in training and games. The aim of the study was to analyze which muscle recovery is most used after soccer game. The study is a narrative review, in which five studies were selected. Inclusion criteria were articles in English and Portuguese, articles from 2009 to 2021 were selected. Exclusion criteria were articles that are not English and in Portuguese, articles before 2009, review studies, dissertations, guidelines and animal studies. The databases udes to search for the studies were Pubmed, Lilacs and Google Scholoar. The descriptors were: soccer and recovery; soccer players and muscle recovery; soccer players and recovery; soccer and recovery; soccer players and rest. The study had a total five articles Where four of them had cryotherapy, two of them being favorable to itself as the best method, passive recovery and the two had better results for it and a massage study. According to the analysis of the studies, active recovery was more effective when compared to cryotherapy and passive recovery. Sports massage has not had significant results, but when recovery periods are short and other methods are not possible.
\end{abstract}

Keywords: Muscle Performance; High Performance Sports; Therapies

\section{Introduction}

Modern soccer began in 1863, when the practice was universalized and the first rules were created. Followed by the English Soccer Association, which until today governs the sport in England (Brazilian Soccer Association, 2021). In Brazil, soccer arrived around 1894 with the return of Charles Miller from England, Where he brought to the country two balls and the explanation of the practice and rules [1]. Its evolution is mainly due to studies and systematizations in various actions in the game, considered a sport with several variables, these studies and systematizations become a very Strong tool for its growth [1]. Physical preparation is a big factor within possible to help maintain player's performance, Where strength, power and intensity are boosted and improved with recovery protocols, given that with the increasingly tight schedule in sport, recovery between efforts gains more and more space to help and maintain the best performance of athletes [2].

In soccer, athletes are exposed to several stimuli Where strength is a fundamental atribute that guarantees their good performance in games [3]. The presence of strength within a soccer game is remarkable, whether in kicks, sprints, races, among others [4]. High-intensity functional performance is directly linked and working together with strength in soccer, sudden changes in directions, slowdowns, within the game are very importante in aiding actions such as dribbling and marking [5]. 
We can highlight power in soccer, among the physical qualities it is one of the most important for good individual performance, being directly linked to game acts such as jumps, kicks and sprints [6]. Jumping power, starting power and deceleration power have a huge importance for soccer [7].

The energy of soccer players is primarily due to aerobic metabolismo, which is related to the ability to maintain a certain intensity by means of rest between high intensity stimuli [8]. Soccer is na intermitente exercise, due to constant changes in intensities in the races, those with high intensity are extremely important in the result of the march [9].

Cryotherapy is the therapeutic application of cold, which can be applied with ice on the subcutaneous skin, resulting in a decrease in muscle and joint temperature, will cause a constriction of venules and arterioles, reducing possible swelling and reducing the risk of injury [10]. It can also be done in cold water immersion, usually up to the waistline, relieving muscle pain and injuries resulting from physical exercise [11]. Cold water immersion has the power to attenuate accumulated muscle metabolic by products, reducing muscle damage caused in athletes, so muscle pain is part of everyday life, cryotherapy has short-term analgesic power, making it an importante tool in the post-game recovery process [12].

Active recovery is a widely used post-exercise recovery model, Where low and moderate intensity exercises are performed [13]. Widely used in soccer, it has been performed between $30 \%$ to $60 \%$ of the maximum energy consumption, with a minimum duration of 15 minutes, it has the power to help the removal of lactate and accelerate the $\mathrm{pH}$ normalization process [14]. Active recovery follows some aspects linking physical capacity, time, type of exercise and intensity [15]. There is a need for more studies regarding active recovery protocols [16]. This study is relevant because it adresses a little-studied issue, which is post game recovery, and it is important for professionals working in the field of soccer, and it is important to analyze how the literature analyzes and adresses this issue.

\section{Objective of the Study}

The objective of the study is analyze which muscle recovery is most used after a soccer game.

\section{Methods}

\section{Types of Study}

The type of study performed is a narrative review with a qualitatiove approach. A narrative review is considered adequate to analyze and presente the general developments of the studies under a qualitative perspective [17]. A qualitative research is not tied to numerical representation, it generatres a depening of an organization, social group, etc. In it, the scientis is the same time the subject and the objective of his research, the development is unpredictable and the researcher's knowledge is limited and partial, with the objective of the sample being to produce in depth and illustrative information, regardless of its size, what is importante is it brings new information [18].

\section{Inclusion and exclusion criteria}

Inclusion criteria were articles in English and Portuguese, articles were selected between 2009 and 2021, the outcome has to be related to some type of recovery the study participants are professional athletes or from base category, be experimental studies. Exclusion criteria are: articles that are not in English and Portuguese, articles before 2009 were also excluded, review studies, dissertation, guidelines and animal studies.

\section{Selection of studies}

The databases used to search for the studies were Pubmed, Lilacs and Academic Google. The descriptors were: soccer and muscle recovery, soccer players and muscle recoverty; soccer play and recovery; soccer and recovery; soccer play and rest. Thus, 213 articles were selected in the databases, 200 were excluded after reading the title, leaving 13 articles (4 PUBMED, 1 LILACS, 8 ACADEMIC GOOGLE); and 8 excluded after reading the abstract. For the final work, three were 5 articles that were published between 2009 and 2019, which will be read in an exhaustive and through manner

\section{Results}

The total number of stud participants was 67 , where all were made with high-level athletes, one of which was a study with professional athletes and the others were from youth categories. Cryotherapy was the most cited type of recovery among the selected articles, followed by passive recovery, which was mentioned in three studies. 


\begin{tabular}{|c|c|c|c|c|c|}
\hline Author & Participants & Objective & Methodology & $\begin{array}{l}\text { Types of } \\
\text { Recovery }\end{array}$ & Results \\
\hline $\begin{array}{l}\text { Bezerra., et } \\
\text { al. } 2015 \text { [19] }\end{array}$ & $\begin{array}{l}19 \text { athletes } \\
\text { professional } \\
\text { medium age } \\
25 \text { years }\end{array}$ & $\begin{array}{l}\text { Evaluate the effect } \\
\text { of cryotherapy im- } \\
\text { mediately after the } \\
\text { game and for three } \\
\text { days of recovery on } \\
\text { muscle pain levels }\end{array}$ & $\begin{array}{l}\text { Athletes were separated into two } \\
\text { groups: GP and GC, after playing } \\
\text { a game. GP performed passive } \\
\text { recovery without and kind of effort, } \\
\text { CG performed immersion in cold } \\
\text { water }\left(10^{\circ} \mathrm{C}\right) \text { up to the waistline } \\
\text { for } 10 \text { minutes. Two hours before } \\
\text { the games, the questionnaire was } \\
\text { applied (Borg's Cr } 10, \mathrm{SPP}) \text { and after } \\
\text { the games, in a period of } 24,48 \text { and } \\
72 \text { hours, the players were submit- } \\
\text { ted to the protocols and answered } \\
\text { the questionnaire again }\end{array}$ & $\begin{array}{l}\text { Passive } \\
\text { Recovery; } \\
\text { Cryoterapia }\end{array}$ & $\begin{array}{l}\text { Cryotherapy has an } \\
\text { analgesic effect obser- } \\
\text { ved by the decrease in } \\
\text { the subjective sensation } \\
\text { of pain }\end{array}$ \\
\hline $\begin{array}{l}\text { Browstein., } \\
\text { et al. } 2019 \\
{[20]}\end{array}$ & $\begin{array}{l}11 \text { athletes } \\
\text { base of cate- } \\
\text { gory medium } \\
\text { age } 22 \text { years }\end{array}$ & $\begin{array}{l}\text { To examine the } \\
\text { effect of wearing } \\
\text { lower body clothing } \\
\text { with CPCM on the } \\
\text { recovery of neuro- } \\
\text { muscular function } \\
\text { after competitive } \\
\text { soccer mathces }\end{array}$ & $\begin{array}{l}\text { The test group players used } \mathrm{CPCM} \\
\text { at } 15^{\circ} \mathrm{C} \text { while the GC used } \mathrm{CPCM} \text { at } \\
\text { room temperature, both for } 3 \mathrm{~h} \text {. }\end{array}$ & $\begin{array}{l}\text { Cryothera- } \\
\text { py through } \\
\text { clothing }\end{array}$ & $\begin{array}{l}\text { The players noticed that } \\
\text { in both outfits they were } \\
\text { moderately effective } \\
\text { in improving recovery, } \\
\text { wtith no difference } \\
\text { beteween the two }\end{array}$ \\
\hline $\begin{array}{l}\text { Ferrari., et } \\
\text { al. } 2013 \text { [21] }\end{array}$ & $\begin{array}{l}23 \text { athletes } \\
\text { of sub-17 } \\
\text { category }\end{array}$ & $\begin{array}{l}\text { Compare different } \\
\text { types of recovery } \\
\text { methods on blood } \\
\text { lactete (La-) remo- } \\
\text { val and anaerobic } \\
\text { performance of } \\
\text { soccer players }\end{array}$ & $\begin{array}{l}\text { Blood samples were collected } \\
\text { during recovery intervals, imme- } \\
\text { diately after and two, four, six, eight } \\
\text { and ten minutes after T1 for blood } \\
\text { lactate measurement, after that } \\
\text { all athletes performed T2 again to } \\
\text { observe the behavior of anaerobic } \\
\text { performance on the three recovery } \\
\text { methods }\end{array}$ & $\begin{array}{rl}\mathrm{PR} & \mathrm{n}=8 \\
\mathrm{AR} n & =8 ; \mathrm{GR} \\
\mathrm{n} & =7\end{array}$ & $\begin{array}{l}\text { There was a greater } \\
\text { removal of blood lactate } \\
\text { for RA, when compared } \\
\text { to GR and PR. Active } \\
\text { recovery proved to be } \\
\text { more eficiente for the } \\
\text { removal of blood lactate } \\
\text { when compared to pas- } \\
\text { sive and active recovery }\end{array}$ \\
\hline $\begin{array}{l}\text { Gassi et al., } \\
2011 \text { [13] }\end{array}$ & $\begin{array}{l}4 \text { athletes of } \\
\text { sub- } 20 \text { cate- } \\
\text { gory }\end{array}$ & $\begin{array}{l}\text { To compare the } \\
\text { effect of different } \\
\text { types of recovery } \\
\text { on the blood lactate } \\
\text { removal speed in } \\
\text { soccer players, after } \\
\text { performing a collec- } \\
\text { tive training }\end{array}$ & $\begin{array}{l}\text { Blood lactate concentration was } \\
\text { measured immediately, after } \\
\text { training, } 10 \text { minutes and } 30 \text { minutes } \\
\text { after. After the end of the collective, } \\
\text { the athletes started the recovery } \\
\text { programs (active recovery, passive } \\
\text { recovery and ice bath) }\end{array}$ & $\begin{array}{l}\text { Active Rco- } \\
\text { very; Passive } \\
\text { Recovery; } \\
\text { Cryotherapia }\end{array}$ & $\begin{array}{l}\text { Active recovery is the } \\
\text { most effective in terms } \\
\text { of speed of lactate remo- } \\
\text { val in high level players } \\
\text { compared to passive. } \\
\text { The ice bath did not } \\
\text { differ significantly from } \\
\text { other recovery strate- } \\
\text { gies }\end{array}$ \\
\hline $\begin{array}{l}\text { Lopes., et al. } \\
2009 \text { [22] }\end{array}$ & $\begin{array}{c}10 \text { athletes of } \\
\text { base category } \\
\text { medium age } \\
\text { of } 15 \text { and } 20 \\
\text { years. }\end{array}$ & $\begin{array}{l}\text { Observe the effecti- } \\
\text { veness of massage } \\
\text { application in rela- } \\
\text { tion to lactate remo- } \\
\text { val after exercise }\end{array}$ & $\begin{array}{l}\text { The sample was divided two } \\
\text { groups: Test Group received the } \\
\text { intervention of sports massage for } \\
\text { a period of } 10 \text { minutes right after } \\
\text { the training session and the Control } \\
\text { Group ( } \mathrm{n}=5 \text { ), did not receive } \\
\text { intervention of sports massage, re- } \\
\text { maining at rest for the same period. }\end{array}$ & $\begin{array}{l}\text { Sports Mas- } \\
\text { sage }\end{array}$ & $\begin{array}{l}\text { Massage for being a } \\
\text { means of recovery when } \\
\text { periods for recovery } \\
\text { are minimal, making } \\
\text { interventions with other } \\
\text { methods impossible }\end{array}$ \\
\hline
\end{tabular}

AR: Active Recovery; CPCM: College Phase Change Material; GC: Control Group; GP: Passive Group; RG: Ice Immersion Recovery; RP: Passive Recovery; SPP: Subjective Perception of Pain; T1: Rast Test; R2: Rast Test. 


\section{Discussion}

The aim of study was to analyze the types of muscle recovery among soccer players after the soccer game. Two studies showed that cyrotherapy is the most effective type of recovery when compared to passive recovery, they Brownstein., et al. [20] and Bezerra., et al [19]. Two studies that compared active recovery with cryotherapy and with passive recovery also gave positive results, which were Gassi., et al. [13] and Ferrari., et al [21]. On the other hand, sports massage had no postive results in recovery see in the study by Lopes., et al. [22].

In the study by Brownstein., et al. [20] a randomized crossover desing in 11 semi-professional players was used for the method, where the season of these players started in August and ended in May and the study took place in the Middle of the season, and the objective was to assess the effectiveness of CPCM in recovery in day following the games. The study took place in six matches, where with five participants the study was carried out in matches one and two, three participants in matches three and four and another three after matches five and six. The test group had the CPCM cooled to $15^{\circ} \mathrm{C}$ and the control group the CPCM was at room temperature. Participants answered a questionnaire where subjective measures of fatigue were evaluated and in the pre-game they answered on a Likert scale how they felt the intervention effectiveness in the pre game and post-game recovery (72 hours). The study concluded the athletes reported believing that the CPCM had an effect, average for recovery and this would be considered an importante finding in the effectiveness of recovery methods for relating intervention with individual preferences.

The study by Bezerra., et al. [19] had a sample of 19 professional players where two groups were separeted: Passive with 11 players and Cryotherapy with 9 participants. For the chracterization of the sample, the players underwent evaluations where height, weight and fat percentage were measured 48 hours before each game and, at the moment, a SSP questionnaire was used. After games, both groups were submitted to intervention in the periods 24,48 and 72 hours after game and answered the SSP questionnaire again. The GP players made their recovery without making any physical effort which consisted of immersion up to the waist line in water at $10^{\circ} \mathrm{C}$ for 10 minutes. In the post-game the level of pain in both groups increased considerably, after 24 hours the GP still had an increase in the level of pain whlie in the CG decreased and in 72 hours the level of pain was normalized for both groups. According to some authors, the short-term level of pain was caused by cryotherapy may be related to the reduction in muscle spindle activity and nerve conduction velocity. Therefore, it should be considered an important method of recovery after high-level games, considering its power in the feeling of recovery, thus occuring in the athletes with better performance in post-game training.

Both studies show us the power of cryotherapy, whether it has an analgesic effect in the short term or even in the athlete's belief after SSP questionnaires. The studies had different methodologies to employ cryotherapy in post-game recovery, where one used CPCM cooled for 3 hours post-game, the other immersed in cold water $\left(10^{\circ} \mathrm{C}\right)$ for 10 minutes 24,48 and 72 hours post-game. The second study brought us better results compared to passive recovery, the first one showed us a small improvement in recovery, but the sensation of pain the athlete's vision had a moderate improvement.

The study by Gass., et al. [11] brought us three recovery models: active recovery, passive recovery and cryotherapy. The sample consisted of four under-20 players from Goias Esporte Clube, the tests were performed after three uninterrupted training sessions lasting 45 minutes, in collective training the minimum period of 72 hours was respected, where removed immediately after collective training, 10 minutes post-training and 30 minutes post-training. The recovery protocols were for $\mathrm{PR}$, the athletes remained seated without making any kind of physical effort for a period of $30 \mathrm{mi}$ nutes, for $\mathrm{AR}$, the athletes performed a continuous troto $\mathrm{n}$ the field for 10 minutes, with an approximate speed of $12 \mathrm{~km} / \mathrm{h}$ in intensity moderate, followed by 20 minutes of passive recovery. In GR, the athletes were submerged up to the waistline in water at $14^{\circ} \mathrm{C}$ for seven minutes in a sequence of 23 minutes of passive recovery. To verify the efficiency of each recovery strategy, the analysis of relative values was performed. The results showed a significance reduction only after 30 minutes, where AR had a reduction of $68,4 \%$, RP $42.9 \%$ and GR 55.2\%. We can highlight the efficiency of AR in terms of recovery and speed in lactic acid removal. The study concludes that AR is more effective for high-level soccer players when compared to PR and GR.

The study by Ferrari., et al. [21] had a sample composed of 23 soccer athletes from the under 17 category, at the club training took place for 4 hours a day, five days a week, with games held on 
weekends. The athletes were submitted to T1 and the divided into three groups, eight athletes made up the PR group, where the athletes were in the sitting position for tem minutes at rest, another eight athletes in the AR group performed a ten-minute run wiht an intensity of $80 \%$ of the critical speed, in natural grass, the last GR group composed of seven athletes, were submerged for 10 minutes up to the waist line in water with a temperature between $8^{\circ} \mathrm{C}$ and $10^{\circ} \mathrm{C}$. The three groups underwent blood collection immediately after $\mathrm{T} 1$ and two, four, six, eight and tem minutes after the test, and $\mathrm{T} 2$ was performed at this second moment to verify the impact of the different recovery protocols. When comparing the peak values of blood lactate after T1 there was no significant difference, however checking the removal of blood lactate AR obtained $47.62 \%$ compared to GR $16.9 \%$ and PR $18.20 \%$ it is concluded that AR is more effective among recovery methods.

The numbers in two studies gave us the power that active recovery has in removing blood lactate after physical effort, when compared to other recovery methods such as cryotherapy and passive recovery, activer recovery had a significant advantage between the protocols. The methodology applied for AR had smoe similarity between the studies, where the first athletes performed a contínuos trot for 10 minutes at moderate intensity with another 20 minutes of PR, as a result there was a blood lactate removal of $68.4 \%$ after 30 minutes of the protocol. The second study was also carried out with the athletes in a race with $80 \%$ of the critical speed there was a removal of blood lactate of $47.62 \%$ after 10 minutes of the protocol.

The studies did not show any evidence about the ineffectiveness of passiver recovery, using it only in comparisson with other recovery methods. The study by Lopes., et al. [22] had a sample of 10 participants, soccer players in the junior category between 15 and 20 years old and they were divided into two groups, the test and the control. The aim of the study was to observe the effect of sports massage on the removal of lactate after physical exercise, the training protocol was elaborated by the club's physical trainer. The study concludes that at the end of the protocol there was no significant difference between the two groups, however during the interverntion the test group $18.7 \%$ faster in removal compared to the control group, so when there is no possiblity of using other protocols, due to short recovery periods, massage can be alternative.

This study is importante for soccer professionals because shows that the literature presentes which type of recovery is most eficien- te, so this provides guidance for professionals in the area for which type of recovery to use in soccer, which is increasingly increasing the amount of games per season, being necessary to be used more efficient methods player's recovery. As limitation of the study, we had the small number of studies related to the area, so we cannot know if these studies were well conducted or not, there were few studies with professional teams, as they play more in the results studies could have been different.

\section{Conclusion}

Activer recovery was more effective when compared to cryotherapy and passive recovery. Sports massage has not had significatn results, but when recovery periods are short and other methods are not possible, it can be used.

\section{Bibliography}

1. Vendite LL., et al. "Scout no futebol: uma análise estatística". Conexões, Campinas, SP 1.2 (2015): 183-194.

2. Moura VA. "A evolução do futebol através da ciência e da tecnologia (2016).

3. Melo G. "Qual a importância da musculação no futebol? (2021).

4. Barboza De Sá D. “Treinamento de força no futebol: mais do que uma realidade, uma necessidade 23 Maio (2012).

5. Pacobahyba N., et al. "Força muscular, níveis séricos de testosterona e de ureia em jogadores de futebol submetidos à periodização ondulatória". Revista Brasileira de Medicina do Esporte 18.2 (2012): 130-133.

6. Dal Pupo., et al. "Potência muscular e capacidade de sprints repetidos em jogadores de futebol". Revista Brasileira de Cineantropometria e Desempenho Humano 12.4 (2010): 255-261.

7. Bompa Tudor 0. "Entrenamiento de la Potencia para el Fútbol”. PubliCE Standard (2003).

8. Silva Juliano Fernandes Da., et al. "Avaliação aeróbia no futebol". Revista Brasileira de Cineantropometria e Desempenho Humano 13.5 (2011): 384-391.

9. Di Salvo V., et al. "Analysis of high intensity activity in Premier League soccer". International Journal of Sports Medicine 30.3 (2009): 205-212.

10. Howatson G and Van Someren KA. "Ice massage: effects on exercise-induced muscle damage". The Journal of Sports Medicine and Physical Fitness 43.4 (2003): 500-505. 
11. Paddon-Jones DJ and Quigley BM. "Effects of cryotherapy on muscle soreness and strength following eccentric exercise". International Journal of Sports Medicine 18.8 (1997): 588-593.

12. Bezerra JA., et al. "Respostas de biomarcadores musculares a uma partida de futebol". Revista Brasileira De Futsal E futebol 6.19 (2014): 58-64.

13. Gassi E., et al. "Efeitos dos diferentes tipos de recuperação sobre a velocidade de remoção do lactato sanguíneo em jogadores de futebol. Vii Congresso Goiano De Ciências Do Esporte Ciência and Compromisso Social: Implicações na/da Educação Física e Ciências do Esporte. Anápolis-GO. Congressoscbce.Org (2011): 1-10.

14. Fairchild T., et al. "Glycogen synthesis in muscle fibers during active recovery from intense exercise". Medicine and Science in Sports and Exercise 35.4 (2003): 595-602.

15. Barnett A. "Using recovery modalities between training sessions in elite athletes: does it help?" Sports Medicine 36.9 (2006): 781-796.

16. Nédélec M., et al. "Recovery in Soccer". Sports Medicine 43.1 (2012): 9-22.

17. Vosgerau DSAR and Romanowski JP. "Estudos de revisão: implicações conceituais e metodológicas”. Revista de Diálogo Educacional 14.41 (2014): 165-189.

18. Gerhardt TE and Tolfo DS. "Métodos de pesquisa. coordenado pela Universidade Aberta do Brasil - UAB/UFRGS e pelo Curso de Graduação Tecnológica - Planejamento e Gestão para o Desenvolvimento Rural da SEAD/UFRGS. - Porto Alegre: Editora da UFRGS (2009): 120.

19. Bezerra JA., et al. "Respostas da crioterapia na sensação subjetiva de dor muscular após o jogo de futebol". Revista Brasileira de Futebol 8.1 (2015): 54-61.

20. Brownstein CG. "The Effect of Phase Change Material on Recovery of Neuromuscular Function Following Competitive Soccer Match-Play". Frontiers in Physiology 10 (2019): 1-12.

21. Ferrari Homero Gustavo., et al. "Efeito de diferentes métodos de recuperação sobre a remoção de lactato e desempenho anaeróbio de futebolistas". Revista Brasileira de Medicina do Esporte 19.6 (2013): 423-426.

22. Lopes AL., et al. "Remoção de lactato em jogadores de futebol após a aplicação de massagem”. Efdeports (2009).
Volume 4 Issue 8 August 2021

(C) All rights are reserved by Vitor Alves Marques., et al. 